\title{
End of journey, end of story? A longitudinal study of involuntary work transitions among laid-off workers
}

Anders Hallqvist and Lars-Christer Hydén

\section{Linköping University Post Print}

\section{Tweet}

N.B.: When citing this work, cite the original article.

This is an electronic version of an article published in:

Anders Hallqvist and Lars-Christer Hydén, End of journey, end of story? A longitudinal study of involuntary work transitions among laid-off workers, 2014, Studies in Continuing Education, (36), 2, 201-217.

Studies in Continuing Education is available online at informaworldTM:

http://dx.doi.org/10.1080/0158037X.2014.904778

Copyright: Taylor \& Francis (Routledge): SSH Titles http://www.routledge.com/

Postprint available at: Linköping University Electronic Press http://urn.kb.se/resolve?urn=urn:nbn:se:liu:diva-109178 


\section{End of journey, end of story? \\ A longitudinal study of involuntary work transitions among laid-off workers.}

\section{Introduction}

The aim of this paper is to increase knowledge of the ways in which individuals who have lost their jobs understand their situations, and how these understandings change over time. The context is what is referred to as the Swedish security agreements and outplacement services based on these agreements. The concept of outplacement means that individuals who face redundancy are not left alone to deal with a job loss; companies are held responsible to some degree, offering financial, consultative and educational support. With a tradition of mutual understanding and cooperation between companies and unions, redundancies and outplacement services in Sweden are often incorporated into the framework of collective agreements (Bergström \& Diedrich, 2008). The arrangement enrolling private and public sector white-collar workers is the most developed of these. In the rest of Europe, too, the use of outplacement services is expanding (Kieselbach, Bagnara, Witte, Lemkow, \& Schaufeli, 2009), and this is why research is needed to examine the consequences of job loss in this particular setting. Previous research on enforced work transitions and job search has pointed to the significance of social networking (Field, 2009), sensemaking (McKee-Ryan \& Kinicki, 2002; Wise \& Millward, 2005), narratives (Ezzy, 2001), learning (Hallqvist \& Hydén, 2012) and identity work (Hallqvist, Ellstrom, \& Hydén, 2012). Looking at the outcome of interventions, research often considers the time between jobs as an important measure, together with the quality of the new employment (in terms of payment and status, cf. Feldman, Leana, \& Bolino, 2002). The difficulties of predicting re-employment success is underscored (Wanberg, 2012). It is important not only to look at people who have reached a new position, however, but also at people who have not. Besides, the many 'precarious' (Kalleberg, 2009) positions question this very distinction. Using a longitudinal research design, in this study we therefore intend to include a variety of different end positions, addressing the question of how people's ways of understanding their situations change over time, i.e. how people understand their situations two or three years after a job loss, compared to the way in which they initially approached it.

\section{Previous research}

Ever since Jahoda's (1971) seminal studies, research has convincingly demonstrated the farreaching social, existential and financial dimensions of unemployment. We are not, however, supplied with as much information when it comes to research on the process of transition ranging from job loss to re-employment. While educational research on transitions has focused mainly on younger people's transitions from educational settings to work (Evans, Behrens, \& Kaluza, 2000; Lundahl, 2011; Nilsson, 2007; Nyström, 2009), today adults make several transitions during their working lives (Fouad, 2007). Moreover, since the middle of the 1990s, ideas of a 'boundaryless' (DeFillippi \& Arthur, 1994) or 'protean' (Hall, 1996) career have been widely discussed and are 
viewed as having an important impact on career theory and research (Sullivan \& Baruch, 2009). The latter term means 'changeable', alluding to the Greek god Proteus with the talent of shifting form. Both concepts point to a decline in job stability and place emphasis on labour mobility, not only as enforced or company-initiated but also strategic and voluntary (Hollister, 2011). Meaning to emphasize rethinking one's career radically, researchers described workers as continuous learners, adaptable and as 'seeking intrinsic rewards' (Sullivan \& Baruch, 2009). However, although the field of career research examines work transitions within and between companies, the focus is mainly on transitions that individuals make autonomously and under optimal circumstances (Fouad \& Bynner, 2008).

Research on enforced transitions, job loss and unemployment has often focused on effects socioeconomic, psychosocial and/or health, for example (Eliasson, 2005; Ezzy, 2001; Hanisch, 1999). Other contributions centre on interventions such as outplacement, including counselling and psychological assessment and their effects (eg. Borgen \& Maglio, 2007) (Westaby, 2004).

Reviewing the past decade's research on unemployment including re-employment issues, Wanberg (2012) emphasizes the difficulties in predicting re-employment success, stating that a myriad of variables' are associated with it (p. 388), pointing to factors such as job search-related predictors, sources of job information and the significance of social networking. Wanberg also finds research on interventions to be heavily underrepresented as compared to research on the difficulties in being unemployed. A comparative investigation (covering Belgium, Germany, the Netherlands, Italy and Spain) shows 'considerable agreement' as to what outplacement should be, but 'discriminations within and across countries' and a lack of equality, in that outplacement counselling 'is not offered to all kinds of employees and in all areas and branches' (Kieselbach, et al., 2009, p. 73). From a Finnish context researchers (Vuori \& Silvonen, 2005) report that job-search interventions lead to higher stable employment and lower psychological distress. They also report that people who were part of the intervention were engaged 'significantly more often in the labour market, either employed, or participating in vocational training' (p. 43) but that no differences were found in job satisfaction.

In studies on interventions, the time running from job loss to re-employment is often considered an important measure (eg. Borland \& Tseng, 2007; Yanar, Budworth, \& Latham, 2009), however McKee-Ryan et al. (2009) argue that interventions should not focus on putting people in jobs and that laid-off workers resolve their unemployment 'only when they find good jobs' (p. 578), pointing to the significance of re-employment quality. Trying to predict this by referring to the job search strategies used, (Koen, Klehe, Van Vianen, Zikic, \& Nauta, 2010) found that a 'focused' and 'exploratory' job search strategy ('openness towards gathering information in a broad and explorative way') led to a greater number of job offers, although the 'exploratory strategy' was negatively related to the quality of the new employment. In the context of the present study, this is an important finding as the intervention that provides the background for the study is generous, meaning that people are offered consultation for a long period, and financial compensation for the 
job loss. Furthermore, participants are encouraged to explore their intentions and expertises when making career decisions.

The concept of 'underemployment' is sometimes used to describe the situation when the process of transition following job loss leads to a job that is 'objectively' and/or 'subjectively' defined as inferior as compared to the previous position (McKee-Ryan, et al., 2009). Clearly, the concept of underemployment is relevant to research on job loss and work transitions, as 'new jobs obtained post -layoff are often inferior to the positions lost' (cf. Kaufman \& Rosow, 1982; McKee-Ryan \& Harvey, 2011, p. 980). Underemployment is not a problem for employees only; the employer is affected too because underemployment is negatively related to job satisfaction (McKee-Ryan \& Harvey, 2011), job involvement (Burke, 1997) and positively related to work alienation (Lee, 2005). Furthermore, looking at work transitions following job loss, re-employment is not the end of the story, as people are faced with new career junctures, and as underemployment in some cases is positively related to further job search efforts (McKee-Ryan \& Harvey, 2011). Overqualified workers, for example, are showed to be more active in job searches (Wald, 2005). In defining underemployment, 'objective' criteria is provided by Feldman (2002). As McKee-Ryan et al. (2009) argue, however, underemployment may also be viewed from the individuals' point of view, as people evaluate their current situations compared to their own expectations and values. In gaining a new position after a work transition, workers can thus consider themselves underemployed if their expectations about their jobs are not met and/or because they consider themselves to be overqualified (Khan \& Morrow, 1991). Describing one's position can be done in many different ways. Besides expectations and qualifications, there are several other arguments and expressions that people may use when understanding and evaluating a new position. As a job loss may be understood as a 'catastrophe' as well as an 'opportunity' or a 'relief', a 'downward' transition or a transition to an unintended position may be defined in different in both positive and negative terms. Likewise, advancement may be defined in different ways, depending on a great variety of conditions, and not forgetting rhetorical abilities.

However, when looking at enforced work transitions supported by outplacement counselling, not only should people who have reached a new position be included, but also people who have not gotten a job and people who have had short-term contracts. Actually, in today's working life when the number of various 'precarious' (Kalleberg, 2009) positions are increasing, the distinction between being employed and being unemployed is not always clear. In order to include a variety of end-positions, in this study the focus is on how people's ways of understanding their situations change over time. To recognize a supposed variety here, to create knowledge regarding how individuals' ways of understanding their situations change over time, research needs to closely examine the stories people tell of the transition and its outcome.

\section{Work transitions as biographical learning}

It this study, enforced work transitions are understood as a biographical learning process (Alheit, 1994; Alheit \& Dausien, 2002). This concept means that during the transition people not only learn 
new job search skills but also learn new ways of understanding their own lives and their relationships to work and the labour market. According to several authors, a process of biographical learning includes reflexive thinking, i.e. people reflecting about themselves and particularly about their life courses. Alheit (1994, p. 290), for example, states that a biographical learning process presupposes 'self-reflexive activities', and Tedder and Biesta (2009b) point out that biographical learning processes may be opened up by 'spaces for reflection' making people 'reflect on their lives' (p. 46).

It is assumed that this biographical learning process affect people's decision-making during a work transition. As people find new positions, new learning will take place and this result in new understanding, which is why the process of biographical learning continues. Biographical learning then unfolds into new biographical learning, and thus there is no end of journey or end of story. The research interview provides yet another opportunity for people to understand their biographies and current positions in working life.

\section{The study}

The research project is part of an ongoing cooperation with two outplacement agencies, TRR Trygghetsrådet and Trygghetsstiftelsen, representing a Swedish way of restructuring and outplacement (Bergström \& Diedrich, 2008; Sebardt, 2006). In the early 1970s the private- and public-sector white-collar unions, together with employer's organizations, developed and signed agreements on transitions that gave workers access to outplacement services when they were made redundant. These agreements form the legal bases of the so-called security councils, TRR Trygghetsrådet and Trygghetsstiftelsen. They are run jointly by the social partners and considered a neutral party in times of restructuring. The particular agreements guarantee relatively generous support, both economically and regarding the educational and counselling arrangements offered. The support offered is individually tailored, and besides financial support, individuals have access to courses, counselling, business advisors and other learning opportunities. Being probably the most ambitious attempts in the Swedish context to deal with the challenge of job loss, these outplacement arrangements provide the background for the present study.

The interview subjects $(n=23)$ were selected and interviewed consecutively over a period of almost one year. The interviewees are white-collar workers but apart from that they represent a variety of occupations (Table 1). Among the interviewees, 15 were 'in transit' and eight had recently finished the outplacement program. Thus, people in the former group were interviewed at a time close to the job loss. They were interviewed once again when more than one year had passed since the first interview. The remaining eight were left out from this particular study as we had not had the opportunity to interview them at the beginning of their journey.

As learning probably is more pronounced and apparent among people whose participation in outplacement counselling has been going on for some time, compared to those who find a new position quickly, we decided in the research group to select people who had been participating in outplacement for more than eight months. Furthermore, we selected 'mid-life' workers, defined as 
individuals 35 to 55 years old. They had to have at least eight years of experience in their sectors, organizations or occupations. These demarcations were made because the challenges connected with work transition would be different for younger people and individuals not yet settled in the labour market, than it is for workers close to retirement.

In a first step the counsellors at two local TRR Trygghetsrådet offices were asked to report to the research group individuals who, besides meeting the above-mentioned criteria, had taken part in training to broaden their professional expertise. Contact was established with those individuals through the outplacement agency, and the interviews were conducted. In a second step, the counsellors at the same two local TRR Trygghetsrådet offices were also asked to report people who, besides meeting the criteria above, had not taken part in training to broaden their professional expertise. In this way we ensured a variation among individuals that covered both ends of a continuum. The subjects were each interviewed once, with the average length of an interview being approximately 70 minutes. The first interview was conducted at least eight months after the notice of job loss and the second interview more than one year after the first interview. The interviews were held at the outplacement bureaus, except for two that were conducted at the interviewee's home and one interview that was conducted by telephone.

The interview guide that was used during these interviews was developed and designed to promote narration by encouraging people to talk about the sequence of events, experiences and actions from the notice of redundancy to the present. In both interviews, the interviewees were asked to tell about their job losses and the subsequent events and actions. To help people recall and develop their narratives, probing questions were asked.

The first author conducted the interviews. Doing the analysis, it was possible to first identify the particular sections in which the interviewees described their situations at the respective interview. Secondly, the individual interviewee's way of describing their situation at the first interview was compared to the way in which he or she described the situation in the second interview. Third, the 15 cases were compared to each other and a variety of approaches were identified. Fourth, a few marked examples were selected and looked at in order to find out if and in what sense people had learned new ways of viewing their own lives in relation to work and the labour market, and in what way people used reflexivity when telling their life histories, i.e. to identify modes of biographical learning.

\section{TABLE}

\section{Findings}

The analysis of the interviews shows that people's positions differed radically. Some of the workers had been re-employed, some had started their own firms, and others had been employed for some 
time but had been made redundant once again. Yet others had not had a job ever since the job loss. Some of the interviewees had experienced major or minor failures in the meantime, e.g. when trying to launch a business project. When comparing the positions held at the respective interview, the basic distinction can be drawn between people who have changed their status and those who have not. In the former group a distinction can be made between people who have reached the position they aimed at in the beginning of the process and people who have gained a job they did not really wish for themselves. Thus, we have two groups, and within the first group there are two sub-groups:

\section{Status changed}
a. intended position
b. unintended position

II. Status unchanged

In the sample, nine had changed their status and six had not. Among the interviewees who had changed their status, four had changed to an intended position and five to an unintended position. However, there were differences within those three groups when looking at the ways in which people rhetorically described their situations. Some people's rhetorical efforts were shown to be stable over time, which indicated that they understood the situation in similar ways on the two different occasions. Others embraced change. Below we will present the findings in more detail and describe the different findings within the groups as rhetorical variations. There will be no attempt to deem whether the transition should be considered as successful or not but we will explore how the changes in people's ways of understanding the transitions can be understood in terms of biographical learning.

\section{Group Ia: Status changed to an intended position}

Within the 'status-changed group' we first have a sub-group of people who have reached a position they aimed at. Looking at this sub-group, findings pointed out two different ways in which peoples' rhetorical efforts change over time. The first concerns a change from describing the situation as characterized by preparation and decision-making, to describing the work transition as successful and completed. This is achieved by people describing their own relationships to current work duties in positive terms, for instance. by referring to work experiences generally and to their confidence and expertise in work related issues. Felicia is one example. She formerly held a position as an engineer, but after losing her job she changed careers, and at the time of the second interview she was working as a teacher. The transition had not been straightforward, however. At the time of the first interview, Felicia expressed her anxiety and doubts about her skills when approaching the career decision; believing that she had chosen the wrong occupation when becoming an engineer, with redundancy she considered a career change. However, finding a new career proved to be difficult: 
I didn't want to return to that kind of work environment any more. What did I want to do? And then we had, at TRR they had one of those 'Have the courage to look for a job' courses - or whatever they call it. And I thought it would build me up, but it was the other way around. I felt I could do nothing (...) I thought it was desperate, really. And what would I do? What would I think? And then I had to act on the basis of what I thought was fun.

The activities at the outplacement bureau made Felicia think searchingly about the situation, raising questions regarding intentions and ambitions. She tried different paths and according to the quotation she claims to have a very precarious position. The way in which she talks about her situation in work life two and a half year later is very different. Now, she uses words that emphasize expertise, dedication and confidence:

I feel I have become a more professional teacher. I can 'read', analyze, in a new way, so I feel more comfortable. And therefore, when I started this class last autumn ... I was much more aware: this is how I want to do it ... I could immediately say: this is this kind of class, that is that kind of class. Then I will choose this level here and that level there. And when I do questions on the homework in that class, then I have prepared a word list for them ... because then they will make it. This class does not need that, because they have this kind of study technique ... suddenly I felt much more professional.

As the excerpt shows, Felicia emphasizes her growing expertise in the field and her ability to deal with the pupils and the different challenges that her new position provides. Using labels such as 'professional teacher' 'I am able to ...', 'I could immediately judge' and 'I was prepared' Felicia claims a position of being confident about her own role as teacher. In other parts of the interview, another aspect of this settledness stands out: dedication. She tells extensively and without many questions about her intentions to develop courses and experiences in meeting the different classes.

Clearly, Felicia has developed a new life story and a new way of presenting her occupational biography. This indicates that she has not only learned new skills but also that she has learned something about her own life. In terms of biographical learning Felicia's case does not illustrate the idea of people constructing general and coherent conceptions of their biographies that are present in the biographical leaning tradition. Instead it points out the use of minor and context-specific biographical accounts to understand and explain one's current situation in life and to provide a basis for action. As a contrast, in the first interview, when Felicia was asked to tell about her decision to make a career change, she developed a story having a wider temporal scope, ranging from childhood to her current situation. Not only was the interview question different, however, but Felicia's situation was also different. As described above, at the time of the first interview, Felicia was very much 'in transition'. She produced a variety of future outlooks and she expressed her uncertainty regarding which one to choose. At the time of the second interview, however, it seems that the existential character of her situation has decreased. Besides the impact of the particular interview question, perhaps this is one reason why Felicia in the second interview refers to everyday challenges rather than to the broad course of her life.

The second rhetorical variety that we would like to point out within this sub-group concerns individuals who despite the new position present themselves as unsettled, in the sense that they keep on looking for new jobs and make use of ambivalent reflexive comments when defining their 
situations. Hannah provides a striking example. At the time of the first interview she had been made redundant from a position working with administrative duties at a local social insurance office.

Defining the notice as a 'strike', she decided to change careers and applied to a course to become a health and wellness trainer. She passed her exam and found a part-time job at a sports association. There she works with physical activity on prescription and is leading different training sessions including water aerobics. Hannah expresses her initial satisfaction with the career change but as the story continues she becomes all the more ambivalent about being employed:

I felt immediately that this was my kind of stuff, I thought it was great ... I was really proud of myself ... I had reached the position I, reached my goal ... To work with ... motivating [people] ... I carried out bicycle ergometer tests ... I had four shifts a weak with water aerobic groups. But then autumn was over and I felt that perhaps this was not heaven on earth. This is not really what I want.

It was precisely three months. Then it was finito, thank you and goodbye. But it could be extended, I knew it could. And I knew they wanted it too. But then I said no. This is enough. I'm not interested in more.

At the same time I have continued at the organization ... four water aerobic lessons a week, plus that I have been trained to become a gymnastics leader ... And I really want to have it like this. But not to be employed.

The whole spring I have looked for jobs ... broadly ... been to interviews, but even so I felt a little that I needed to take a step back when it got closer ... I do not want to be permanent, tied and locked in again.

Then this May they called from a staffing agency and said that now we have a job ... as responsible for finances ... perhaps 10 hours a week. I can do the work more or less when I like, when it suits me ... So I leaped at it ... And also I look after our family company at home. And right now I feel it is gold. This is precisely what I want.

As the last sentence shows, subjectivity rules when Hannah describes her career decision-making. Further, the account is interspersed with reflexive comments. Repeatedly referring to her own different and contrasting moods, short-lived preferences, what is 'my kind of stuff', what 'suits' and what she 'feels' at particular moments, Hannah presents herself as unpredictable, elusive and unsettled, and as a person with a strong sense of independence. She applies for jobs but 'takes a step back when it got closer'. To be employed by the staffing agency for only one year is 'perfect' because she does not want to be 'permanent and tied'. Thus, Hannah claims to be continuously on the move, unwilling to be caught by any employer.

Hannah's case provides a distinct example of a new 'protean' career pattern but also of a rhetorical strategy for career decision-making that makes marked use of reflexivity as a way to convince the listener regarding the reasonableness of it, and thus to make the career decision socially valid. What is striking, however, is that, although Hannah appears to be changeable, when comparing the two interviews Hannah's approach shows to be stable over time. And this, in turn, means that there is not very much biographical learning in Hannah's case, despite her intense and recurrent selfreflexive efforts. As reflexivity is central to biographical learning (eg. Alheit \& Dausien, 2002; Tedder \& Biesta, 2009b) this fact deserves further consideration. Rather than providing an opportunity for learning about one's life, Hannah's reflexive comments seem to support the status 
quo. Reflexivity probably serves rhetorical and social purposes rather than providing an opportunity for learning.

\section{Group Ib: Status changed to an unintended position}

Looking at the second sub-group, findings again pointed out two different patterns. The first is similar to the 'settled' one referred to above. Even when a new position is not the intended one, sometimes people define the transition as successful and completed. The second version is more change-oriented and concerns individuals whose approaches change from creativity and agency to a more passive and adaptive approach. This is illustrated below by the case of Jessica. After her job loss the 39-year-old executive official decides to try something radically different, and starts higher education to become an estate agent. At the time of the first interview, she had finished her first course and begun the second one. She had also established strong ties to a local estate agent, and this form provided an opportunity for practice and also paid work during the summer period:

I [saw] there was an course programme to become an estate agent assistant and it sounded really exciting ... I thought I'd go down and talk to [a local estate agent] and he said 'yes, I am really interested but I would prefer an estate agent' and then I started to think a little about that and looked for education ... And that is what I have started now.

I have begun with law and finances now. I had no higher education credits earlier, so I need to get through all the courses. One needs to follow a certain order, to be qualified for the next course.

I have one more year, or one and a half before I am finished, depending on how I well I do on the exams.

Now I feel this is exciting, it is a really exciting journey I'm taking. And now I have worked at this estate agent during the summer, and done my training.

Telling the story of her emerging career change, Jessica was enthusiastic and expectant. The exit from her previous job is defined as a chance to try something different. At the time of the second interview, Jessica has ended her studies, however. She has been unemployed for more than a year, though recently before the time of the second interview she was employed by a staffing company. Though she defines the current position as in accordance with her interest in real estate and in buildings, she expresses her disappointment over how things have turned out. When explaining what has happened, Jessica refers to the rules that regulate the unemployment benefits; as she was not allowed to study when receiving unemployment benefits, she decided to quit her studies:

My unemployment benefit fund did not [allow] me to receive funding and study at the same time. So then I was really disappointed. So then I was only a job-seeker at the public employment service to get my unemployment benefits and then I was at home seeking jobs for a long time ... And now I have got a position at Manpower. They hire me out to the public building planning office ... The time at the estate agency as well as my studies have been very useful to me, because I am working with real estate in the municipal, the estate agency. So that was probably the reason why they let me in, because I had this in my baggage I believe. That I had the knowledge from the studies and had worked a little or had some insight into it

Instead of studying and writing exams, Jessica has been at home, being unemployed for more than a year. But even though Jessica is disappointed, she is grateful for the new job, and she stresses that her recent studies and the practice at the estate agency have been important in getting this job. 
In terms of biographical learning, in the first interview, Jessica was heading towards a major biographical change including both creative action and sense-making efforts. At the time of the second interview, this learning process has come to a standstill, or has changed character from a pronounced to a more restricted approach. Perhaps it was the regulation of the unemployment fee that made Jessica put on the brakes. Another important difference in a comparison between the first and second interviews concerns the institutional context. This seems to be important in both cases; when making the radical career decision, Jessica gained recognition and social support from the outplacement agency, and when making the opposite career decision, the formal relationship to the institution administrating the unemployment benefits seems to be decisive. Career decision-making could probably be considered as a 'joint' or 'relational' undertaking (Hallqvist, 2012) which is dependent on not only strong ties but also on formal ties. Still there is evidence of biographical learning in Jessica's account. Referring to her experiences at the estate agency as important 'baggage' that provided access to the new position, Jessica links together divergent projects in her life course, in order to present her biography in a 'coherent' manner.

\section{Group II: Status unchanged}

In this group some people keep on searching for jobs similar to the ones they lost, but with no success. Clearly, this does not include very much reflexivity or reconsideration. The other stable but different approach suggests that sometimes people keep on broadening their outlooks and knowledge, for example by taking courses or trying new career intentions or business projects, in order to become more employable. Both indicate that, although time is getting on, the strategies people use to deal with their situation do not seem to change.

But besides those stable approaches, sometimes people in this group used other rhetorical efforts in the second interview as compared to the first. For example, some presented reduced visions, or more down-to-earth career intentions. This is exemplified in Jessica's case, above, and could be thought of in terms of adaptation to the environment. People probably perceive some challenges as more difficult to handle than others, and some visions as more difficult to make happen than others. Isaac provides an example. In the first interview, he talked extensively about visions regarding being an author and about a related business project centring on lecturing on different topics such as leadership or creativity. He was about to make a radical career change and talked a bit disparagingly about his previous occupations. Considering himself to be a 'slacker', now he was about to demonstrate his potential. He was about to 'come out of the closet' and to 'gear up ...' his career:

It is sort of ... I was about to say that I have 'come out of the closet' and well [Interviewer: laugh] ... perhaps a little. No, but I have stepped onto the stage anyway. I have been working inconspicuously and ... perhaps not always got the recognition for it or like that. And then it feels like this is a new phase for me perhaps, that, that 'Well, but then, then you have to stand up for what you are doing' and, and, and show yourself and try to see if it will work. 'Can you make a living without hiding in the wings?' So then it's a little more like, that 'it's time to roll up your 
sleeves and get into the limelight' like that, and 'to wax or wane'. I feel it's like that. So, it's a new ... like gearing up, it is. At least I see it like that. To be forced [laugh] to step up a gear.

The problem is that Isaac has not taken any concrete steps to make his visions materialize, apart from deciding the title of his coming book and designing his firm's logotype. Thus, even though Isaac makes far-reaching sense-making efforts to create meaning in his biography, for instance by describing the change with metaphors such as 'gearing up' and 'coming out of the closet', this mode of biographical learning is somewhat 'idealistic' because nothing really happens. Two years later, in the second interview, there still are major visions but there are also more modest ones:

So I won a position at the ... international programs office ... as information specialist ... and I worked there for half a year ... it was a little like living in a suitcase ... I got another supply job in the autumn as EU administrative officer ... So I sat and did administration during the autumn ... they let me know I could stay another half a year.

[A company] needed an information specialist on short notice for a three-month period ... so I sent them my papers ... and then I have been working with ... this book which has an autobiographical background ... there are two ways ... I search for these jobs, which are short-term ... and if I don't get any job and run past of the insurance system then I will begin driving taxis, because I got, through Trygghetsstiftelsen, they let me get a ... taxi-driving licence ... and then I have thought about a combination of writing and driving taxis.

During the time since the first interview, Isaac has had short-term contracts with different employers, working with duties similar to his previous ones. The vision of becoming an author remains, but beside that there are 'minor' visions about different positions and, as a final way out, to become a taxi driver. Over time Isaac has thus moved away from the 'idealistic' mode of biographical learning and come closer to what has been called an 'agentic' mode (Hallqvist, et al., 2012). This is characterized by departure from routine and the use of novel action strategies and by sense-making efforts that emphasize continuity rather than contrast, when comparing his previous career with his future working life. Still, as Isaac is not settled in a new position; there may well be new turns in the road to come, and new modes of biographical learning.

Another rhetorical variation tries to capture a tendency saying that sometimes people tend to set aside the idea of realizing their career intentions in favour of non-employment-related life projects. Gabriel, for example, defined himself at the time of the first interview in terms of becoming a teacher, but after several unsuccessful attempts to gain a teaching position, at the time of the second interview he does not consider his options to ever get a job as teacher as very good. And when asked about his previous career intentions, he says that after the job loss he 'wanted to do something else' but that he didn't know what, and that he still doesn't know. He talks extensively, however, about having quality time, that is, being at home and working with different projects in the garden, like building a greenhouse: '... the older one becomes, the more one realizes that, that, time, one's own time, one's quality time, becomes more and more valuable ... It is worth very much, when I do whatever I like to do'. Even so, Gabriel continues to take part in teacher education, however the studies are not mainly aimed at gaining employment, but rather at the 
intrinsic values of reading, reflecting and thinking. has While he continues to study because of these values, Gabriel makes his living by working as a driver.

Comparing Gabriel's answers in the two interviews, the analysis shows a marked contrast. While he valued the time spent at home at the first interview too, it has become more important as his efforts to get a job have not turned out very well. By referring to his age ('as you are growing old...') and the related 'insight' regarding the value of his 'own' time, in the second interview Gabriel presents his current position in the context of his overall life course. This, together with the way in which he emphasizes non-employment projects, suggests that he understands his life differently in the second interview. This in turn indicates biographical learning.

A final variation within the same group concerns a change from a reflective and flexible approach to what we choose to label 'severe' reflexivity. It is about individuals who have tried to adjust to the labour market by changing career orientation, but without attaining the proper job. Compared to the other variations in this group, these people's directions are not clear. They express ambivalence and their answers are characterized by the absence of marked conclusions.

At the time of the first interview, Diana emphasized her flexibility and talked a lot about several changes and recurrent new career decisions. Actually Diana began the first interview by declaring a brand new change, describing her decision to 'return' to the industrial sector, after having tried to move into economy/administration through a course and a trainee position. At the time of the second interview adaption remains the main strategy, but her reflexive approach is even more accentuated:

Well, it was like, I was, mentally, on the way into the stockroom and industrial world. But it is probably because, well, I have felt that I want to work administratively. But at the same time I have, sort of, seen that, my god: how many women aren't unemployed who have been working at some office and who ... then I have nothing compared to what they have. Certainly I will not be considered if I try for such positions. So I have laid that down, and I haven't dared to hope for it. But now I saw the chance here, and I like it very much. So I just feel, my god, where have I been, searching around for two or more years? Because I won't work in industry, that's not me. This is my place, I feel. Well, it doesn't have to be precisely here, but...

Diana uses a reflexive strategy to such a degree that in some sentences she does not seem to reach a point or conclusion, but she continues to deliberate back and forth, and back again to a different standpoint. In this account, she repeatedly halts, evaluates and tries a new and different argument. Note the many 'but's in the excerpt. Rather than a way to resolve a difficult situation, reflexivity as carried out in this interview situation, appears to be a burden laid upon her when she tries to make her previous career decisions socially valid to the interviewer. Diana's case is reminiscent of Hannah's, above, as both define their positions by ambivalent reflexive comments when they evaluate events, actions and career decisions. At the same time, there are major differences between them as Hannah's flexibility and part-time unemployment is voluntary, while Diana desperately tries to be flexible and struggle to assimilate to the labour market but without succeeding in getting a job.

\section{Discussion}


When reading the findings it is importat to keep in mind the particular setting, which above was described as a 'Swedish way' of restructuring and outplacement (Bergström \& Diedrich, 2008; Sebardt, 2006). This probably stands out as relatively generous from an international outlook, and can also be viewed in relation to other Nordic or Scandinavian 'flexi-curity' approaches.

Looking at how individuals' ways of dealing with enforced work transitions change over time, the study has pointed to both stable and change-oriented patterns. The findings show that a view according to which work transitions are considered to be unfolding in either re-employment $o r$ continuing unemployment is too simplistic. When looking at how people themselves define their situations, evidence points out many different 'end positions'. And, of course, there is no 'end' of journey because people, as well as employers, continue to make new decisions that, in turn, produce the 'protean' (Hall, 1996) careers of our time. This fact, as well as the expansion of 'precarious' (Kalleberg, 2009) employment, suggests that the borderline between being employed and being unemployed is blurred. To a greater extent than before, employers in working life today are shown to be unpredictable, seeking short-term relationships. However, sometimes employees seem to pay back in the same coin, referring to changing moods and short-lived preferences. This suggests that not only are labour market rules and resources changed, but also what is considered as a culturally appropriate career outlook. This confirms the observation that the 'psychological contract' (Atkinson, 2002) has changed during recent decades.

Regarding how people understand and deal with enforced work transitions, the similarity between some of the versions in the different groups and sub-groups above suggests that the main division is not between people who have gained employment and those who have not, but between people using different rhetorical strategies and, in turn, different modes of biographical learning.

As was stated above, the concept of biographical learning includes the idea of reflexivity, i.e. that people reflect on their own lives, and because of this practice, learn from their lives. This means that the presence of reflexive comments in people's life stories is considered to have learning potential. In has been shown above, however, that reflexivity is not homogenous, and that the concept of biographical learning could gain from recognizing a variety of reflexive patterns within the concept.

It has also been claimed above that not only does the production of general life stories play a role in work transitions, but also minor, concrete and context specific accounts that have a much more restricted temporal scope. The question concerning the significance of the overall life story is a matter of discussion in the field of narrative psychology (McAdams \& Cox, 2010, p. 169). While some authors emphasize this, considering that 'constructing a life story that integrates the remembered past and imagined future to provide a convincing, unifying, and purposeful account of life' is one developmental tasks of adult individuals (McAdams \& Cox, 2010, p. 169), others question whether this is doable and if one's narrative identity really can be captured in a single synthesizing story, suggesting that one's stories are many and diverse (Raggatt, 2006). In the case of Felicia, above, the particular interview context and the specific subject and questions that Felicia is asked to deal with probably affect the temporal scope of the narrative. However the temporal 
scope is also dependent on the phase of the transition, in the sense that the general life story has an important role to play when our lives are changing, but is replaced by everyday stories when people are 'settled' in their new positions. From the current study it is not possible to claim that this is the case; this is only suggested as a possible explanation.

While reflexivity in the biographical learning tradition is considered to be productive, in the cases of Diana and Hannah it is not obvious what comes out of it. Hannah's case shows that sometimes the praxis of reflexivity is not very productive, but it does preserve a present outlook. It seems that the use of reflexivity can turn into a habit, confirming the observation that sometimes people are caught in their stories (Tedder \& Biesta, 2009a). Moreover, sometimes reflexivity is not only unproductive but also exhausting, as in the case of Diana. Alheit emphasizes the creative potential of reflexive identity work, pointing out the 'surplus of meanings' present in people's biographies, saying that in biographical learning processes, people keep the 'references to self fundamentally open' (1994, p. 89). Yet sometimes people's reflexive efforts are 'bounded' (Evans, 2007) by concrete realities. It is not self-evident that stories have the potential to change structures (Glastra, Hake, \& Schedler, 2004), but it depends very much on the concrete and specific sociomaterialistic conditions. Diana has tried out different occupational paths with no success, and even in the present situation she does not manage to close the case and end her story. Thus, reflexivity as a vital part of biographical learning shows a different face, compared to its productive role in the biographical learning tradition.

Both Hannah's and Diana's cases are reminiscent of Sennett's (1998) notion regarding the consequences of working in the 'new capitalism', not in the sense that Diana's and Hannah's respective characters are subject to 'corrosion' but in the sense that flexibility is not without victims and is not self-evidently countered by biographical learning. According to this view, reflexivity is not the solution but part of the problem.

It is important to recognize that reflexivity is a communicative practice that not only produces learning on the part of the storyteller but also serve rhetorical purposes. This means that it is used to claim certain positions and identities. It seems that Hannah utilizes reflexivity to position herself as steered by subjective moods and changing preferences; she is unpredictable, elusive, unsettled and independent. And by Diana's 'severe' reflexivity with no marked conclusions, she positions herself as rather desperate and lacking a clear direction or future outlook. In the absence of normative, culturally established norms or points of reference, autobiographical reflexion may be the one and only option at hand that helps people define their positions in (working) life and define what is a good job.

Finally, the significance of 'non-employment life projects' as part of people's career stories raises questions regarding the meaning of paid work to peoples' well-being. Though work probably continues to provide meaning and social context to people's lives, according to Beck (2000) in late modern society the new world of work produces and presupposes biographies that are not based on the idea of continuous and lifelong employment but are giving way to a less stable world of work with recurrent changes between formal employment and 'civil' and self-organized activities. This is 
illustrated in the case of Gabriel and the way in which he talks about his non-employment-related life projects. This suggests that in today's working life when the straightforward career pattern is supplemented by 'protean' careers, it might be important not to renounce and disparage phases with no paid work. Unemployment, then, need not be an overwhelming problem; it could instead be turned into a positive and enriching discontinuity of the life course.

\section{Acknowledgements}

Thanks to two anonymous reviewers for valuable comments.

\section{References}

Alheit, P. 1994. The 'biographical question' as a challenge to adult education. International Review of Education, 40(3), 283-298.

Alheit, P., \& Dausien, B. 2002. The double face of lifelong learning: Two analytical perspectives on a silent revolution. Studies in the Education of Adults, 34(1), 3-22.

Atkinson, C. 2002. Career management and the changing psychological contract. Career Development International, 7(1), 14-23.

Beck, U. 2000. The brave new world of work. Cambridge: Polity.

Bergström, O., \& Diedrich, A. 2008. The Swedish model of restructuring. In B. Gazier \& F. Bruggeman (Eds.), Restructuring work and employment in Europe: managing change in an era of globalisation (pp. 141). Cheltenham: Edward Elgar.

Borgen, W. A., \& Maglio, A. S. T. 2007. Putting action back into action planning: experiences of career clients. Journal of Employment Counseling, 44(4), 173-184.

Borland, J., \& Tseng, Y. P. 2007. Does a minimum job search requirement reduce time on unemployment payments? Evidence from the jobseeker diary in Australia. Industrial and Labor Relations Review, 60(3), 357-378.

Burke, R. J. 1997. Correlates of under-employment among recent business school graduates. International Journal of Manpower, 18(7), 627-635.

DeFillippi, R. J., \& Arthur, M. B. 1994. The boundaryless career: A competency based perspective. Journal of Organizational Behavior, 15(4), 307-324.

Eliasson, M. 2005. Individual and family consequences of involuntary job loss. Göteborg: Department of Economics, Göteborg University.

Evans, K. 2007. Concepts of bounded agency in education, work, and the personal lives of young adults. International Journal of Psychology, 42(2), 85-93.

Evans, K., Behrens, M., \& Kaluza, J. 2000. Learning and work in the risk society: Lessons for the labour markets of Europe from Eastern Germany. Basingstoke: Macmillan.

Ezzy, D. 2001. Narrating unemployment. Aldershot: Ashgate.

Feldman, D. C., Leana, C. R., \& Bolino, M. C. 2002. Underemployment and relative deprivation among reemployed executives. Journal of Occupational and Organizational Psychology, 75(4), 453-471. 
Field, J. 2009. Learning transitions in the adult life course: Agency, identity and social capital. In B. Merrill (Ed.), Learning to change? The role of identity and learning careers in adult education (pp. 17-31). Frankfurt: Peter Lang.

Fouad, N. A. 2007. Work and vocational psychology: Theory, research, and applications. Annual Review of Psychology, 58, 543-564.

Fouad, N. A., \& Bynner, J. 2008. Work transitions. American Psychologist, 63(4), 241-251.

Glastra, F. J., Hake, B. J., \& Schedler, P. E. 2004. Lifelong learning as transitional learning. Adult Education Quarterly, 54(4), 291-307.

Hall, D. T. 1996. Protean careers of the 21st century. The Academy of Management Executive (1993-2005), 10(4), 8-16.

Hallqvist, A. 2012. Occupational transitions as a relational project. Studies in Continuing Education, 34(2), 83-98. doi: 10.1080/0158037x.2011.610300

Hallqvist, A., Ellstrom, P. E., \& Hydén, L. C. 2012. The many faces of biographical learning. Studies in the Education of Adults, 44(1), 70-84.

Hallqvist, A., \& Hydén, L. C. 2012. Learning in occupational transitions: A study of the process following job loss. Work: A Journal of Prevention, Assessment and Rehabilitation, 43 (3), 331-343.

Hanisch, K. A. 1999. Job loss and unemployment research from 1994 to 1998: A review and recommendations for research and intervention. Journal of Vocational Behavior, 55(2), 188220.

Hollister, M. 2011. Employment stability in the U.S. labor market: Rhetoric versus reality. Annual Review of Sociology, 37(1), 305-324. doi: doi:10.1146/annurev-soc-081309-150042

Jahoda, M., Lazarsfeld, P. F., \& Zeisel, H. (1971). Marienthal: The sociography of an unemployed community-Translated by the authors with John Reginait and Thomas Elsaesser: Chicago: Idine-Atherton.

Kalleberg, A. L. 2009. Precarious work, insecure workers: Employment relations in transition. American Sociological Review, 74(1), 1-22.

Kaufman, H. G., \& Rosow, J. M. 1982. Professionals in search of work: Coping with the stress of job loss and underemployment: Wiley: New York.

Khan, L. J., \& Morrow, P. C. 1991. Objective and subjective underemployment relationships to job satisfaction. Journal of Business Research, 22(3), 211-218.

Kieselbach, T., Bagnara, S., Witte, H. D., Lemkow, L., \& Schaufeli, W. (Eds.). (2009). Coping with occupational transitions: An empirical study with employees facing job loss in five

European countries. Wiesbaden: VS Verlag.

Koen, J., Klehe, U. C., Van Vianen, A. E. M., Zikic, J., \& Nauta, A. 2010. Job-search strategies and reemployment quality: The impact of career adaptability. Journal of Vocational Behavior, 77(1), 126-139.

Lee, C. H. 2005. A study of underemployment among self-initiated expatriates. Journal of World Business, 40(2), 172-187.

Lundahl, L. 2011. Paving the way to the future? Education and young Europeans' paths to work and independence. European Educational Research Journal, 10(2), 168-179.

McAdams, D. P., \& Cox, K. S. 2010. Self and identity across the life span. Handbook of lifespan development. Vol. 2 (pp 158-207). New York: Wiley.

McKee-Ryan, F. M., \& Harvey, J. 2011. "I have a job, but...": A review of underemployment. Journal of Management, 37(4), 962-996.

McKee-Ryan, F. M., \& Kinicki, A. J. 2002. Coping with job loss: A life-facet perspective. International Review of Industrial and Organizational Psychology (Vol. 17).

McKee-Ryan, F. M., Virick, M., Prussia, G. E., Harvey, J., \& Lilly, J. D. 2009. Life after the layoff: getting a job worth keeping. [Article; Proceedings Paper]. Journal of Organizational Behavior, 30(4), 561-580. doi: 10.1002/job.566 
Nilsson, S. 2007. From higher education to professional practice: A comparative study of physicians' and engineers' learning and competence use. Linköping: Department of Behavioural Sciences and Learning, Linköping University.

Nyström, S. 2009. Becoming a professional: A longitudinal study of graduates' professional trajectories from higher education to working life: Linköping University Electronic Press.

Raggatt, P. T. F. 2006. Multiplicity and conflict in the dialogical self: A life-narrative approach. In D.P. McAdams, R. Josselson, and A Lieblich (Eds.) Identity and story: Creating self in narrative (pp. 15-35). Washington DC: American Psychological Association Press.

Sebardt, G. 2006. Redundancy and the Swedish model in an international context. Alphen aan den Rijn: Kluwer Law International.

Sennett, R. 1998. The corrosion of character: the personal consequences of work in the new capitalism. New York: W.W. Norton.

Sullivan, S. E., \& Baruch, Y. 2009. Advances in career theory and research: a critical review and agenda for future exploration. Journal of Management, 35(6), 1542.

Tedder, M., \& Biesta, G. 2009a. Biography, transition and learning in the lifecourse. The role of narrative. In J. Field, J. Gallacher \& R. Ingram (Eds.), Researching transitions in lifelong learning (pp. 76-90). Abingdon: Routledge.

Tedder, M., \& Biesta, G. 2009b. What does it take to learn form ones life? Exploring opportunities for biographical learning in the lifecourse. In B. Merrill (Ed.), Learning to change? The role of identity and learning careers in adult education (pp. 33-47). Frankfurt: Peter Lang.

Vuori, J., \& Silvonen, J. 2005. The benefits of a preventive job search program on re-employment and mental health at 2-year follow-up. Journal of Occupational and Organizational Psychology, 78(1), 43-52.

Wald, S. 2005. The impact of overqualification on job search. International Journal of Manpower, 26(2), 140-156.

Wanberg, C. R. 2012. The individual experience of unemployment. Annual Review of Psychology, 63(1), 369-396. doi: 10.1146/annurev-psych-120710-100500

Westaby, J. D. 2004. The impact of outplacement programs on reemployment criteria: a longitudinal study of displaced managers and executives. Journal of Employment Counseling, 41(1), 19-28.

Wise, A. J., \& Millward, L. J. 2005. The experiences of voluntary career change in 30-somethings and implications for guidance. Career Development International, 10(5), 400-417.

Yanar, B., Budworth, M. H., \& Latham, G. P. 2009. The effect of verbal self guidance training for overcoming employment barriers: A study of Turkish women. Applied Psychology, 58(4), 586-601. 


\begin{tabular}{|c|c|c|c|c|c|c|c|c|c|c|c|c|}
\hline & نேّ & 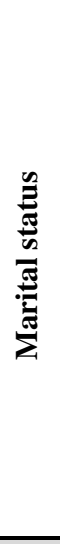 & 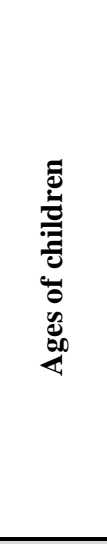 & 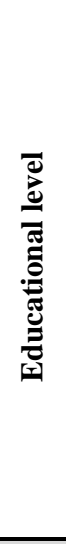 & $\ddot{\infty}$ & 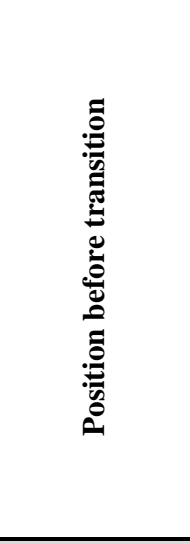 & 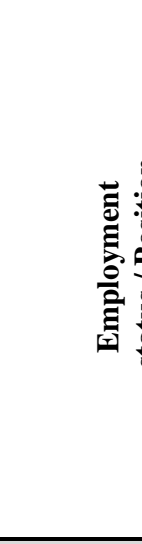 & & 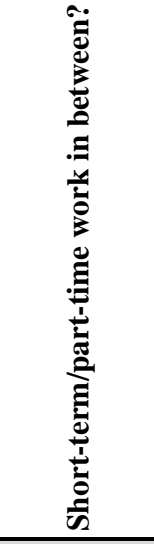 & 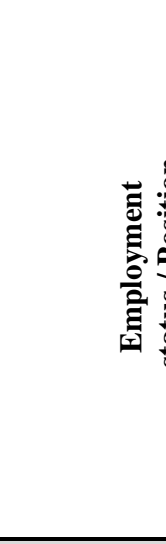 & & 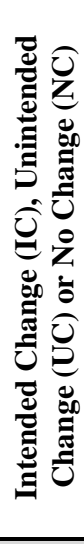 \\
\hline Ann & $\mathrm{F}$ & $\mathrm{S}$ & 21,24 & $\mathrm{SH}$ & 53 & $\begin{array}{c}\text { Business } \\
\text { administrator }\end{array}$ & $\begin{array}{c}\text { Un- } \\
\text { employed }\end{array}$ & $\begin{array}{c}\text { Future } \\
\text { entrepre } \\
\text { neur } \\
\end{array}$ & $\begin{array}{l}\text { Entrepren } \\
\text { eur }\end{array}$ & $\begin{array}{c}\text { Tempo- } \\
\text { rary part } \\
\text { time worker } \\
\end{array}$ & $\begin{array}{l}\text { Project } \\
\text { manager }\end{array}$ & UC \\
\hline Britt & $\mathrm{F}$ & $\mathrm{P}$ & 6,8 & SH & 38 & Postal worker & $\begin{array}{c}\text { Un- } \\
\text { employed }\end{array}$ & Student & No & $\begin{array}{c}\text { Tempo- } \\
\text { rarily } \\
\text { employed }\end{array}$ & $\begin{array}{l}\text { Social } \\
\text { worker }\end{array}$ & IC \\
\hline Carl & M & $\mathrm{P}$ & 14,17 & SH & 41 & $\begin{array}{l}\text { Key account } \\
\text { manager }\end{array}$ & $\begin{array}{c}\text { Un- } \\
\text { employed }\end{array}$ & $\begin{array}{c}\text { Future } \\
\text { entrepre } \\
\text { neur }\end{array}$ & $\begin{array}{l}\text { Entrepren } \\
\text { eur }\end{array}$ & \multicolumn{2}{|c|}{ Business owner } & IC \\
\hline Diana & $\mathrm{F}$ & $\mathrm{S}$ & - & $\mathrm{SH}$ & 41 & $\begin{array}{l}\text { Assistant } \\
\text { nurse/ } \\
\text { Industrial } \\
\text { worker } \\
\end{array}$ & $\begin{array}{c}\text { Un- } \\
\text { employed }\end{array}$ & $\begin{array}{c}\text { Job } \\
\text { seeker }\end{array}$ & $\begin{array}{l}\text { Stockpile } \\
\text { Administr } \\
\text { ation }\end{array}$ & $\begin{array}{l}\text { Unem- } \\
\text { ployed }\end{array}$ & Job seeker & $\mathrm{NC}$ \\
\hline Erik & M & $\mathrm{P}$ & $\begin{array}{c}10, \\
13,21\end{array}$ & UI & 45 & $\begin{array}{l}\text { Key account } \\
\text { salesperson }\end{array}$ & $\begin{array}{c}\text { Un- } \\
\text { employed }\end{array}$ & $\begin{array}{c}\text { Future } \\
\text { entrepre } \\
\text { neur }\end{array}$ & No & \multicolumn{2}{|c|}{ Business owner } & $\mathrm{NC}$ \\
\hline Felicia & $\mathrm{F}$ & $\mathrm{P}$ & $\begin{array}{c}5,9 \\
12\end{array}$ & $\mathrm{U}$ & 41 & Engineer & $\begin{array}{l}\text { Un- } \\
\text { employed }\end{array}$ & $\begin{array}{c}\text { Future } \\
\text { entrepre } \\
\text { neur/stu } \\
\text { dent } \\
\end{array}$ & Teacher & Employed & Teacher & IC \\
\hline Gabriel & M & $\mathrm{P}$ & - & $\mathrm{U}$ & 51 & $\begin{array}{l}\text { Agricultural } \\
\text { manager }\end{array}$ & $\begin{array}{l}\text { Tempo- } \\
\text { rarily, } \\
\text { part-time } \\
\text { employed } \\
\end{array}$ & Student & Driver & $\begin{array}{l}\text { Tempo- } \\
\text { rarily, part- } \\
\text { time } \\
\text { employed } \\
\end{array}$ & Student & UC \\
\hline Hannah & $\mathrm{F}$ & $\mathrm{P}$ & 7,10 & SH & 40 & Administrator & $\begin{array}{c}\text { Un- } \\
\text { employed }\end{array}$ & Student & Trainer & $\begin{array}{l}\text { Part-time } \\
\text { employed }\end{array}$ & Trainer & IC \\
\hline Isaac & M & $\mathrm{P}$ & 16,18 & SH & 49 & $\begin{array}{l}\text { Communica- } \\
\text { tion } \\
\text { specialist }\end{array}$ & $\begin{array}{c}\text { Un- } \\
\text { employed }\end{array}$ & $\begin{array}{c}\text { Job } \\
\text { seeker } \\
\text { /Future } \\
\text { entrepre } \\
\text { neur } \\
\end{array}$ & $\begin{array}{l}\text { Communi } \\
\text { cation } \\
\text { specialist }\end{array}$ & $\begin{array}{l}\text { Tempo- } \\
\text { rarily } \\
\text { employed }\end{array}$ & $\begin{array}{l}\text { Communi } \\
\text { cation } \\
\text { specialist }\end{array}$ & UC \\
\hline Jessica & $\mathrm{F}$ & $\mathrm{P}$ & 15,17 & SH & 39 & $\begin{array}{l}\text { Executive } \\
\text { official }\end{array}$ & $\begin{array}{c}\text { Un- } \\
\text { employed }\end{array}$ & Student & $\begin{array}{l}\text { Admini- } \\
\text { strator }\end{array}$ & $\begin{array}{c}\text { Tempo- } \\
\text { rarily } \\
\text { employed } \\
\end{array}$ & $\begin{array}{l}\text { Admini- } \\
\text { strator }\end{array}$ & UC \\
\hline Katrine & $\mathrm{F}$ & $\mathrm{P}$ & $\begin{array}{c}18, \\
26,28\end{array}$ & $\mathrm{SH}$ & 50 & $\begin{array}{l}\text { Executive } \\
\text { official }\end{array}$ & $\begin{array}{c}\text { Tempo- } \\
\text { rarily, } \\
\text { part-time } \\
\text { employed } \\
\end{array}$ & $\begin{array}{c}\text { Job } \\
\text { seeker }\end{array}$ & $\begin{array}{l}\text { Entrepren } \\
\text { eur }\end{array}$ & $\begin{array}{l}\text { Unem- } \\
\text { ployed }\end{array}$ & Job seeker & UC \\
\hline Louise & $\mathrm{F}$ & $\mathrm{P}$ & 4,7 & SH & 45 & Purchaser & $\begin{array}{c}\text { Un- } \\
\text { employed }\end{array}$ & $\begin{array}{c}\text { Job } \\
\text { seeker }\end{array}$ & $\begin{array}{l}\text { Sales- } \\
\text { person }\end{array}$ & $\begin{array}{l}\text { Unem- } \\
\text { ployed }\end{array}$ & Job seeker & $\mathrm{NC}$ \\
\hline Olivia & $\mathrm{F}$ & $\mathrm{S}$ & 17,18 & UI & 45 & $\begin{array}{c}\text { Assistant } \\
\text { bookkeeper }\end{array}$ & $\begin{array}{c}\text { Un- } \\
\text { employed }\end{array}$ & $\begin{array}{c}\text { Job } \\
\text { seeker }\end{array}$ & No & $\begin{array}{l}\text { Unem- } \\
\text { ployed }\end{array}$ & Job seeker & $\mathrm{NC}$ \\
\hline Robert & M & $\mathrm{P}$ & 14 & S & 47 & Logistician & $\begin{array}{c}\text { Un } \\
\text { employed }\end{array}$ & $\begin{array}{c}\text { Job } \\
\text { seeker }\end{array}$ & Logistics & $\begin{array}{l}\text { Unem- } \\
\text { ployed }\end{array}$ & Job seeker & $\mathrm{NC}$ \\
\hline Therese & $\mathrm{F}$ & $\mathrm{P}$ & 13 & SH & 44 & $\begin{array}{l}\text { Marketing } \\
\text { manager }\end{array}$ & $\begin{array}{l}\text { Un- } \\
\text { employed }\end{array}$ & $\begin{array}{c}\text { Job } \\
\text { seeker } \\
\text { and } \\
\text { student }\end{array}$ & Marketing & $\begin{array}{l}\text { Unem- } \\
\text { ployed }\end{array}$ & $\begin{array}{c}\text { Job } \\
\text { seeker/stu } \\
\text { dent }\end{array}$ & $\mathrm{NC}$ \\
\hline
\end{tabular}

